FOLIA POMERANAE UNIVERSITATIS TECHNOLOGIAE STETINENSIS

Folia Pomer. Univ. Technol. Stetin., Agric., Aliment., Pisc., Zootech. 2020 357(56)4, 31-44

Received 17 Aug 2020

Revised 12 Oct 2020

Oliwia MAŃKO

Accepted 14 Oct 2020

\title{
THE PROPOSAL FOR MONITORING OF GOLDEN JACKAL (Canis aureus)
}

Faculty of Animal Breeding, Bioengineering and Conservation, Warsaw University of Life Sciences - SGGW, Poland

\begin{abstract}
Golden jackal (Canis aureus) is a mesopredator. As an opportunistic species, it can both compete and pose a threat to native species. The golden jackal was first documented in Poland in 2015, where it came probably due to the natural expansion of the species distribution range. Currently, its estimated population size is based only on observations of single individuals, but this may change in the future. The recent expansion of the golden jackal, as well as its small population size in Poland, result in a low level of knowledge about this species and its impact on the native fauna and flora. The purpose of monitoring is to help in the future control of the population size, as well as to facilitate the acquisition of knowledge on the biology and the impact of this species on the environment. The monitoring method of the golden jackal presented in this article consists of the assessment of both the species' habitat and its population. Overall, the proposed assessment of the habitat and population is based on evaluation of 7 indicators (population density, number of litters, height above sea level, presence of wolves, access to water reservoirs, scrubs, food base availability). Indicator assessment allows to determine, whether a given site is favorable for the settlement and growth of the golden jackal population. Observations carried out during the monitoring process may additionally facilitate the recognition of the species in the newly occupied areas, and allow to determine its impact on the environment.
\end{abstract}

Key words: golden jackal, monitoring.

\section{INTRODUCTION}

Golden jackal (Canis aureus) is a mesopredator, that was recently recorded in Poland. Unfortunately, there exists no described method of this species' monitoring. The aim of this work is to summarize biology of the golden jackals and to propose a method of their monitoring, thus facilitating future endeavours evaluating its impact on the native fauna and flora, and preparing the management plan for its populations.

1. Taxonomy (Hoffmann et al. 2018)
a. Order: Carnivora
b. Family: Canidae
c. Genus: Canis
d. Species: golden jackal Canis aureus (Linnaeus, 1758)

2. Legal and conservation status

a. International law

Corresponding author: Oliwia Mańko, Faculty of Animal Breeding, Bioengineering and Conservation, Warsaw University of Life Sciences - SGGW, Ciszewskiego 8, 02-786 Warszawa, Poland, e-mail: omanko@interia.pl 
Council Directive 92/43/EEC of May 21st 1992 on the conservation of natural habitats and of wild fauna and flora - Annex $\mathrm{V}$

b. National law

The Act of October 13th 1995, Game law [in Polish];

Regulation of the Minister of the Environment of July 31st 2017, amending the regulation on establishing the list of game species [in Polish];

Regulation of the Minister of the Environment of August 1st 2017, amending the regulation on determining the hunting seasons for game animals [in Polish].

c. IUCN Red List category

LC - least concern (Hoffmann et al. 2018)

\section{Description}

Golden jackals are mesocarnivores (Bošković et al. 2015), comparable in size to a cocker spaniel (Giannatos 2004). The longest-lived individual of golden jackal was registered in the Serengeti and it lived for 14 years (Sillero-Zubiri et al. 2004). They have golden fur, but with variation of different shades (from light, through creamy yellow to dark colors) (Sillero-Zubiri et al. 2004), there can also occur animals with more red, golden-brown or even silver fur (Giannatos 2004). The hair on their back are often a mixture of black, brown and white, thus resembling a saddle. The belly and parts of the hind paws are lighter in color (Sillero-Zubiri et al. 2004). The unique, lighter patterns found also on golden jackals' head, throat, chest and limbs, enable the identification of particular individuals (Macdonald 1979; Sillero-Zubiri et al. 2004; Giannatos 2004). The tip of the tail often bears hair of black color.

The legs are quite long, in relation to the body length, while pads are relatively small (Sillero-Zubiri et al. 2004), as was corroborated by the work of Bošković et al. (2015), where they found that the width of golden jackals' paws measured: front $-3.5 \mathrm{~cm}( \pm 0.16 \mathrm{~cm})$, hind $-3.3 \mathrm{~cm}( \pm 0.3 \mathrm{~cm})$.

The average length of the body of golden jackals in Croatia and Serbia documented by Bošković et al. (2015) was approximately $85 \mathrm{~cm}( \pm 5.5 \mathrm{~cm})$, while according to Giannatos (2004) the body length in this species ranges from 120 to $125 \mathrm{~cm}$, jackals' tails reached, on average $24 \mathrm{~cm}( \pm 1.6 \mathrm{~cm})$ in length, height at the withers measured $47.6 \mathrm{~cm}( \pm 2.7 \mathrm{~cm})$, and the length of the ears $7.8 \mathrm{~cm}( \pm 0.3 \mathrm{~cm})$.

The skull of golden jackal resembles more that of coyote (Canis latrans) and grey wolf (Canis lupus), rather than of other jackals (Black-backed jackal (Canis mesomelas) and side-striped jackal (Canis adustus)) (Lapini et al. 2009).

Golden jackals have 42 teeth and their tooth pattern is - 3/3 1/1 4/4 2/3 (Sillero-Zubiri et al. 2004). Young golden jackals, up to the age of 5-7 months, have a double canine (Lapini et al. 2009).

The weight of a golden jackal ranges from 8 to $15 \mathrm{~kg}$ (Golden Jackal - Canis aureus facts, https://www.lcie.org/Large-carnivores/Golden-jackal, access: 11.07.2020), therefore it is larger than such species as the red fox (Vulpes vulpes), or raccoon dog (Nyctereutes procyonoides), which also occur in Poland. Whereas it is similar to that of a European badger (Meles meles), whose body weight varies between 11-16 kg (Mańko 2020).

Inexperienced observers may easily confuse adult golden jackals with large red foxes (Vulpes vulpes) (Lapini et al. 2009), while juvenile golden jackals resemble grey wolf puppies (Canis lupus) (Karolewska 2019).

Some golden jackals have a so-called "horn", which is the bone that grows from the occipital bone (Karolewska 2019). 
A characteristic feature of the golden jackals are the connate pads on the medial digits of the forelimbs (Kowalczyk et al. 2015) what facilitates tracking of their movement (Fig. 1).

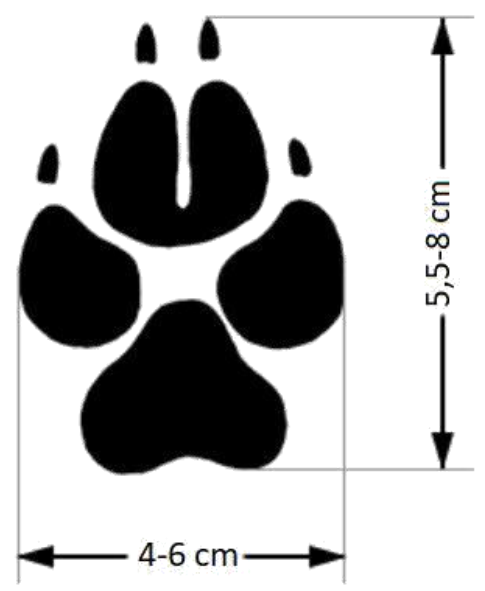

Fig. 1. The size of the golden jackal's track and its characteristic feature - connate pads

Source: Szakal złocisty. Informator dla kół łowieckich, http://www.cietrzew78.pl/SZAKAL.pdf, access: 11.07.2020.

\section{Ecology and behavior}

Golden jackals are an opportunistic predators, with a diverse diet. They hunt their prey, but may also feed on carrion (Gherman and Mihalca 2017). Golden jackals show great flexibility in using various hunting strategies to acquire food (Markov and Lanszki 2012).

Diet of golden jackals includes: small mammals, birds and their eggs, amphibians, reptiles, invertebrates, carrion and occasionally vegetables and fruits (Markov and Lanszki 2012; Gherman and Mihalca 2017). According to Sillero-Zubiri et al. (2004) jackals can hunt for Thomson's gazele (Eudorcas thomsonii). In addition, it has been observed that golden jackals may also feed on anthropogenic food (e.g. garbage or remains from a slaughterhouses) (Sillero-Zubiri et al. 2004; Golden Jackal..., https://www.lcie.org/Large-carnivores/Golden-jackal).

The diet of the golden jackal resembles the diet of native species, such as the red fox (Vulpes vulpes) or the European badger (Meles meles) (Mańko 2020). Their hunting strategies are also similar (Ćirović et al. 2016).

Single individuals hunt mainly for smaller prey (e.g. rodents), mostly by locating the prey by hearing and then jumping on it. They can also dig food out of the ground. Golden jackals may also hunt in larger groups consisting of several individuals. The presence of golden jackals was linked to damage in crops and livestock (Sillero-Zubiri et al. 2004). However, golden jackals are not a persistent hunters, but rather gatherers and scavengers (Giannatos 2004).

The social organization of golden jackals' groups varies depending on many factors, including the availability of food. The base of the golden jackal group is the parent pair, which may be accompanied by the current and previous litter. The couple marks their area by urinating and defecating, especially around burrows (Sillero-Zubiri et al. 2004). Jackals can leave single droppings of feces or whole "piles" reaching up to $1 \mathrm{~m}$ in diameter or in the form of lines (Macdonald 1979).

Research conducted in the Balkan Peninsula showed that in areas where golden jakckals are common, their density ranges from 0.1 group per $10 \mathrm{~km}^{2}$, in areas less favorable for the species, to even 1.1 group per $10 \mathrm{~km}^{2}$ in area where jackal is abudant, and in some 
particularly favorable areas, their density reaches 4.8 group per $10 \mathrm{~km}^{2}$. The difference in group density may also be attributed to the intensity of land use (Šálek et al. 2014). Jackals occupy areas ranging in size from 1.1 to $20 \mathrm{~km}^{2}$ (Gherman and Mihalca 2017). Although their territories may overlap, the central part is always used only by a particular family (Karolewska 2019). In areas where food is plentiful, such groups may reach as many as 10-20 individuals (Jenks et al. 2015).

Jackals are typically nocturnal animals, although in areas where there are no humans, they also come out of hiding during the day, but they hide right away after hearing humans (Giannatos 2004; Jenks et al. 2015). Golden jackals can travel up to $12-15 \mathrm{~km}$ to get food. Occasionally, non-breeding individuals can stay in the vicinity of a food source (e.g. carrion) for several days before returning to their territory (Sillero-Zubiri et al. 2004). Recent research conducted in Hungary documented that a single female golden jackal was able to migrate the distance of $223.7 \mathrm{~km}$ in 12 days. That jackal was found to travel most of the distance at night (6 pm - 6 am) (Lanszki et al. 2018).

There are many affiliate behaviors in golden jackals, such as group vocalizations or welcoming rituals. The vocalizations are quite distinctive and complex, starting with 2-3 simple low tones and ending with staccato high notes. It is easier to make jackals howl, and a single individual can quickly cause nearby individuals to howl (Sillero-Zubiri et al. 2004). Their characteristic howl is usually a nightly event in areas where jackals are abundant. However, it is not so common in areas where the density of jackals is low, and when only single, migraing individuals are found in a given area (Giannatos 2004). In India, it has been observed that howling is more frequent from December to April, possibly due to pairing and designating territories (Sillero-Zubiri et al. 2004). Warning signals were also documented in golden jackals, they differ from normal howling and are presented mainly when there is a danger nearby, e.g. a large predator (Sillero-Zubiri et al. 2004). Although golden jackals have been shown to howl quite often, counting of single individuals by listening to the howling is impractical, as it is usually impossible to distinguish individuals from within the pack (Macdonald 1979).

Golden jackals reach sexual maturity at 11 months of age, but most juveniles are likely to stay with the parent pair for the next year as "helpers" for the next litter. Heat occurs once a year, usually in January-March (Giannatos 2004). As with other canines, copulation usually takes few minutes. Gestation lasts about 63 days (Giannatos 2004; Sillero-Zubiri et al. 2004). The time of childbirth coincides with the abundance of food, so it largely depends on the locality. Puppies are born blind and open their eyes after about 9 days, and their teeth begin to grow after about 11 days. Lactation usually lasts 8-10 weeks. Both parents and „helpers” look after the puppies, protect them and provide them with food. Food is also provided to the female during pregnancy and lactation by the rest of the pack (Sillero-Zubiri et al. 2004). There are usually 2 to 10 puppies in the litter (Giannatos 2004). However, the average litter size depends on the region, e.g. in Tanzania it is 5.7 puppies, in India it is 3.6 (Sillero-Zubiri et al. 2004), and in Bulgaria 5.9. In contrast, litters larger than 10 puppies occur once in 100 litters (Giannatos 2004).

It is worth mentioning, that all Canis species can theoretically interbreed and produce offspring. In theory, hybridization may be considered a natural behavior, but it can also be caused by human activity and may adversely affect future relationships between humans and the previously mentioned species (Karolewska 2019). 
Giannatos (2004) documented that golden jackals may be outcompeted by grey wolves. This may mean that the presence of wolves is an important factor shaping the distribution of golden jackals. Foxes are considered to avoid areas with golden jackals, while badgers may even share burrows with jackals. As for dogs, they usually react aggressively to jackals (Giannatos 2004).

\section{Habitat}

Due to golden jackals' broad environmental tolerance, they are found both in semideserts, such as the Sahel, and in the evergreen forests of Thailand. They also occupy Savannah, mangroves, various types of forests, rural areas and semi-rural areas or grasslands. They can venture into the vicinity of households in search for food (Sillero-Zubiri et al. 2004). Additionally, it was found that in some cases packs of jackals have territories within an average distance of $2.6 \mathrm{~km}$ from buildings (Giannatos 2004).

In Ethopia, golden jackals have been registered at an altitude of 3800 meters above sea level (Sillero-Zubiri et al. 2004).

Golden jackals are adapted to occur in almost all habitats, except in extreme deserts and very dense forests (Giannatos 2004). In addition, they are not adapted to survive in deep snow or in cold climates, due to their relatively short legs, small paws and coat not adapted to low temperatures (Spassov and Acosta-Pankov 2019).

Research conducted by Giannatos (2004) has shown that jackals prefer lowland wetlands with scrubs, and maquis areas.

Research conducted in Greece has shown that for resting, as well as during breeding, jackals prefer areas covered with dense scrubs that are difficult for humans and pets to penetrate. The ideal environment, in addition to dense scrubs, is not far from open space such as meadows or small farmlands where jackals can hunt (Giannatos 2004).

6. Distribution in Poland

The golden jackal is a species that is now widely distributed in Europe, Asia and Africa (Arnold et al. 2012). Golden jackals probably colonized Europe during the late Holocene and early Neolithic (Gherman and Mihalca 2017).

Waves of golden jackals' expansion documented in the 20th century (especially two: in 1950s and 1980s (Gherman and Mihalca 2017)) indicate an increase in the range of this species to the north of the continent. Currently, the number of golden jackals in Europe is growing (Trouwborst et al. 2015).

The arrival of the golden jackals in Poland, is probably due to natural expansion of their distribution, but exact reasons remain unknown (Trouwborst et al. 2015). Factors that influence the dispersion of the species include: great adaptability and its plasticity (Jenks et al. 2015; Ćirović et al. 2016), climate warming (Giannatos 2004; Arnold et al. 2012; Spassov and Acosta-Pankov 2019), environmental changes (Bošković et al. 2015), and a small or absent grey wolf population (Canis lupus) (Arnold et al. 2012; Giannatos 2004).

It was only in January 2015, when a golden jackal was shot in the Czech Republic, about $6 \mathrm{~km}$ from the border with Poland (Kowalczyk et al. 2015). It proved the growing range of the golden jackals' population and the possibility of the arrival of this species in Poland. The first three observations of golden jackals in Poland were described by Kowalczyk et al. (2015). Localization of these observations (a dead individual and two photos) may indicate multiple arrival directions of this species to Poland (Kowalczyk et al. 2015). 
The proposal for monitoring of golden jackal (Canis aureus) was based on the data contained in the Animal species monitoring guide published by the Inspectorate for Environmental Protection (Makowska-Juchniewicz 2010).

\section{METHODS OF MONITORING}

\section{The concept of species monitoring}

Monitoring includes regular measurements and observations of phenomena or species. The purpose of monitoring is to collect information that helps to plan appropriate activities in the future.

Monitoring described in this guide aims to help assess the population status of a new species in Poland - golden jackal. In addition, it is planned to collect data on the habitats that can be inhabited by the golden jackal for the sake of forecasting where the species may appear later.

This research aims to assess where in Poland the golden jackal is or may be present in the future, and in addition, the collected data can help to better understand the biology and impact of the jackal on other species. In the future, this data might help in planning population management.

\section{Indicators and assessment of the species conservation status}

Indicators of the population and habitat status are presented and described in the table (Table 1). Then the method of valorization of the given indicators is presented (Table 2).

Table 1. Indicators of the population and habitat status of the golden jackal (Canis aureus).

\begin{tabular}{|c|c|c|}
\hline Indicator & Measurement & Method \\
\hline \multicolumn{3}{|l|}{ Population } \\
\hline Population density & $\begin{array}{l}\text { number of individuals } \\
\mathrm{N} \text { per } 1000 \mathrm{~km}^{-2}\end{array}$ & $\begin{array}{l}\text { Full inventory based on tracking, registration of the other } \\
\text { traces of the species presence (e.g. feaces); the number } \\
\text { of individuals is checked over an area of } 100 \mathrm{~km}^{2} \text { and } \\
\text { then the density per } 1000 \mathrm{~km}^{2} \text { is calculated; annually }\end{array}$ \\
\hline Presence of litters & $\begin{array}{l}\text { presence, signs or } \\
\text { absence of litters }\end{array}$ & Observations conducted during the inventory \\
\hline \multicolumn{3}{|l|}{ Habitat } \\
\hline Height above sea level & {$[\mathrm{m}]$} & $\begin{array}{l}\text { Data on height above sea level taken from verified } \\
\text { resources; every } 10 \text { years }\end{array}$ \\
\hline Presence of grey wolves & $\begin{array}{l}\text { number of individuals } \\
{\left[\mathrm{N} / 100 \mathrm{~km}^{-2}\right]}\end{array}$ & $\begin{array}{l}\text { Full inventory, data on the distribution of packs in } \\
\text { Poland downloaded from the monitoring of this species; } \\
\text { annually }\end{array}$ \\
\hline Access to water reservoirs & presence of reservoir & $\begin{array}{l}\text { Record the presence of a water reservoir within } 30 \mathrm{~km} \\
\text { from the site and verify its periodicity; every } 3 \text { years }\end{array}$ \\
\hline Scrubs & {$[\%]$} & $\begin{array}{l}\text { Percentageous scrub (plant formation up to } 2 \mathrm{~m} \text { in height) } \\
\text { coverage of the total area studied; calculated e.g. using } \\
\text { GIS; every } 3 \text { years }\end{array}$ \\
\hline Food base availability & $\begin{array}{l}\text { presence of a food } \\
\text { base }\end{array}$ & $\begin{array}{l}\text { Amount of available food sources (small mammals, } \\
\text { birds and their eggs, amphibians, reptiles, inverte- } \\
\text { brates, carrion, vegetables and fruits, anthropogenic } \\
\text { waste) within } 30 \mathrm{~km} \text { from the site; every } 3 \text { years }\end{array}$ \\
\hline
\end{tabular}


Table 2. Valorization of the population and habitat status indicators of the golden jackal (Canis aureus)

\begin{tabular}{|c|c|c|c|}
\hline Indicator/ Evalution & FV & U1 & U2 \\
\hline \multicolumn{4}{|l|}{ Population } \\
\hline $\begin{array}{l}\text { Population density } \\
\text { Presence of litters }\end{array}$ & $\begin{array}{l}>0.5 \\
\text { litters present }\end{array}$ & $\begin{array}{l}0.5-0.1 \\
\text { signs of the possibility } \\
\text { of the appearance of } \\
\text { a litter (digging burrows, } \\
\text { mating pairs) }\end{array}$ & $\begin{array}{l}<0.1 \\
\text { no signs of littering/ } \\
\text { single individuals }\end{array}$ \\
\hline \multicolumn{4}{|l|}{ Habitat } \\
\hline Height above sea level & $<300$ (lowland) & 300-500 (upland) & > 500 (mountains) \\
\hline Presence of wolves & $<2$ & $2-3$ & $>3$ \\
\hline Access to water reservoirs & reservoir present & periodic reservoir & no presence of reservoir \\
\hline Scrubs & $>50$ & $30-50$ & $<30$ \\
\hline Food base availability & $\begin{array}{l}\text { access to all food } \\
\text { sources (8) }\end{array}$ & $\begin{array}{l}\text { availability of some } \\
\text { food } \\
\text { sources (5-7) }\end{array}$ & $\begin{array}{l}\text { access to a limited } \\
\text { number of food } \\
\text { sources (less than 5) }\end{array}$ \\
\hline
\end{tabular}

FV - proper condition, U1 - condition unsatisfactory, U2 - bad condition.

* The size of the desity assumed for the current condition of the species in Poland, in the event of an increas in the status, the parameters for assessment should be changed.

\section{Assessment of the state of the population}

Due to the close relationship between both population status indicators (population size and presence of litters), the final assessment of the state of the population equals the lowest score either of them.

\section{Assessment of the habitat condition}

The impact of each factor should be taken as part of the impact on the overall assessment of the habitat's condition. A numerical value should be assigned to individual grades (e.g., $\mathrm{FV}=3, \mathrm{U} 1=2, \mathrm{U} 2=1$ ) and the final value should be calculated by adding component points and dividing them by 5 (number of indicators). The habitat status assessment is the result rounded according to the Polish standard for approximation of numbers (Number: PN-N$-02120: 1970)$.

\section{Prospects of maintaining the population}

The assessment of the prospects of maintaining the population of the golden jackals at a given site should be an expert judgment and should include such elements as:

1. Assessment of whether there is a possibility of further development of the population at a given site.

2. Checking if there are no barriers preventing further migration (such as large buildings, the presence of a large packs of wolves in given forest complex, high mountains, etc.).

3. Assessment of neighboring habitats in terms of the possibility of colonization by a golden jackal.

4. Checking for investments planned in the vicinity of the evaluated site, which may have a negative impact on the golden jackals population.

5. Assessment of other threats that may affect the population (such as poaching, poisoning carrion, infrastructure development, etc.). 


\section{Overall assessment}

The overall assessment cannot be given a single rating due to the limited range of the species in Poland and its individual sites. Here, the assessment of the state of the population and the assessment of the condition of the habitat should be provided separately, showing the current state of the population and the potential of the habitat for the development of the population.

\section{Selection of the site for monitoring}

The site is an area where the expert has confirmed the presence of the golden jackal, based on a photo or genetic examination of biological material. In the case of a golden jackals, whose population in Poland is characterized by a small number, constant monitoring should be carried out every quarter of the year, in the areas where the presence of this species has been confirmed. Futher monitoring areas should also be incorporated in the event of confirmation of a new sites by an expert.

In other areas of Poland that can be colonized by jackals, information on the condition of the habitat and population should be collected once a year.

\section{Assessment of population status indicators}

Tracking along transects

At the sites where the golden jackals have been observed, monitoring can be carried out by registering tracks, faeces, urine marking, howls, burrows, and direct observations of individuals. Only in the case of continuous monitoring in a given area it can be excluded that the individual was a migrating animal or only temporarily staying at a given position.

Data should be collected by authorized individuals (including employees of forest districts, parks, hunters, etc.). Then, the observational data should be plotted on a generally available forms for the golden jackal observations. However, only forms filled by authorized individuals, or forms with an additional proof of sighting (e.g. a photo of a jackal), will be taken into account when examining the population status indicators.

For each site and for areas where golden jackals may appear, the Regional Directorate of the State Forests, in consultation with the Polish Hunting Association and with national and landscape parks, if there are any in a given area, should determine the coordinatorsupervising the work of all units that monitor jackal and collecting data on the species in the area.

Most of the methods used to monitor all kinds of species, will not work for a population as small as the golden jackal population. Therefore, monitoring should be carried out in several ways and the condition of the population should be assessed based on a summary of all observations.

Tracking along transects aims to determine whether there is a golden jackal within a given area and if yes, then how many are there. Additionally, the conducted genetic research can help to determine the direction from which the golden jackals arrived to Poland, but the analysis should be submitted to appropriate laboratories adapted for this type of research. The molecular study should account for the golden jackals' capability of forming hybrids with other species. 
To perform this type of tracking, the appropriate transects must first be selected. It is recommended to select such transects that in their center there is a place of confirmed observation of a golden jackal.

The regional coordinator selects the day when tracking will be performed. Previously, the coordinator, together with other people engaged in carrying out the monitoring, select the transects along which they will move. Each transect should be covered within one day. The transect should be an area not less than 50 meters wide and not less than 500 meters long. People involved in monitoring should be spaced approximately 5 meters apart and record all signs of jackals existence and activity. All biological samples, such as faeces, should be collected and undergo genetic testing. All observations such as tracks (their size, direction, number of individuals), droppings (single and "piles"), howling of jackals and other observations should be recorded on the map and in the transect tracking form. Additional documentation such as photos of the tracks can be attached to the final form. Then maps and forms should be sent by the coordinator to the center coordinating jackal monitoring.

\section{Registration of burrows}

In selected areas that have been marked as areas where there may be a golden jackal, the burrows that are used and can be habitable should be registered. Such burrows should be observed for at least a week in the evening hours (after 7:00 p.m.), for at least 2 hours in order to check what species inhabiting the burrow.

\section{Camera trap}

Camera traps should be used where the presence of a golden jackal and the use of burrows has been confirmed. The camera trap should be setup to register animals entering and leaving the burrow. This method of monitoring is aimed at checking the number of jackals and their ability to breed.

\section{Year-round observations}

Year-round observations cannot be considered a method as there is no methodology described for them. Additionally, they often cannot be verified or repeated, but they are a widespread method for determining the presence and abundance of a given species (Okarma and Tomek 2008).

Year-round observations should be based on observations carried out by people constantly working in the field, such as foresters, hunters, etc. Systematic observations recorded on the forms facilitate the control of the jackal population and the identification of new sites where it occurs. Such observations, after entering them into the form, should be sent by the coordinator to the center coordinating the jackal monitoring.

Forms should record such observations as: individuals observed (preferably together with evidence of their observations in the form of a photo attached as an attachment to the form), dead individuals (the form should be completed in the same way as in the case of live specimens), locations of single excrements and "piles", howling jackals (preferably record the sound and send as an attachment with the form), tracks (preferably together with evidence of observation such as a photo attached as an attachment to the form, including something for size comparison in case it is not possible to accurately measure the track), and others. Date, time and location should be provided for all observations, and in addition, if possible, age, sex and number of individuals. 


\section{Collection and interpretation of population monitoring data}

The data collected during the above-mentioned observations are collected by monitoring centers in given regions and then sent to the national center, coordinating jackal monitoring. All data is entered into a computer databases (comprising: date, time, location, additional information), and then individual observations are plotted on topographic maps of Poland using GIS techniques. On the basis of the presented data, the population of the golden jackal in the country is studied. All centers coordinating monitoring and coordinators have access to databases.

\section{Complementary methods}

Assessment of habitat condition indicators

A complementary method may be genetic monitoring (DNA analysis from biological samples). This type of monitoring not only can help in the exact identification of the species, but also allows to distinguish individuals, enabling the determination of the minimum number of individuals in a given area. In addition, this method allows to check whether interbreeding between jackals and other species occurs in Poland.

Habitat condition assessment, should be made every 3 years if there is water reservoirs, bushes and the food base available, and every year in case of the presence of wolves.

In the event of an exceptional situation (e.g. fire) in a given area, the frequency of analyzes of indicators should be increased.

\section{Timing and frequency of monitoring}

Tracking on transects should be carried out at the end of winter, and subsequent tracks after 6 months (2 tracking per year). In the event of new site appearing, tracking should be carried out in such area as soon as possible.

Other types of jackal monitoring can be carried out while monitoring other species, or continuously throughout the year.

Information reported to the national jackal monitoring center should be sent quarterly (March, June, September and December) for jackal sites and once a year in areas where there is no jackal but there are habitats that can be colonized by them.

Newly observed jackal sites should be reported immediately to the national jackal monitoring center, or to the coordinator.

The unit coordinating the monitoring of the golden jackal in Poland should be the Mammal Research Institute of the Polish Academy of Sciences in Białowieża.

Jackal monitoring should be carried out every year, because the situation of this species in Poland is not clear, and it would be necessary to better understand the range of its occurrence.

The season of determining the habitat status indicators is indifferent.

\section{Equipment and materials for research}

A national center coordinating jackal monitoring should be equipped with appropriate equipment enabling the filling and analysis of databases, with GIS software installed. In addition, equipment enabling the auditioning of the recordings should be provided to enable verification of the recorded howls of the jackal. 
Observation forms are generally available to anyone who monitors jackals, additionally, when tracking on transects, you can use counting forms.

In the case of a complementary method, the monitoring coordinating center should provide adequate sampling kits and finance the performance of analyzes.

\section{Species with similar ecological requirements for which this monitoring can be adapted}

Taking into account the habitat preferred by the jackal, the diet and the size of the species, it can be assumed that the species with similar requirements to the jackal are the European badger (Meles meles) and the red fox (Vulpes vulpes).

In the case of the jackal and the above-mentioned species, both tracking on transects and the registration of burrows can be carried out jointly, at the same time.

\section{Conservation of the species}

The golden jackal in Poland is currently found at individual sites. It is difficult to determine what the population of this species will look like in the future. In order to learn about the dynamics of population changes and the distribution of jackals in the country, monitoring should be carried out. As the jackal was not brought to Poland by humans, but appeared there through the natural expansion of distribution range, it should not be considered an invasive species. Research on the real impact of the jackal on the fauna and flora of Poland should be carried.

Further plans regarding the status of the golden jackal in Poland must be undertaken when the situation of this species in the country stabilizes and becomes better known.

\section{CONCLUSIONS}

The golden jackals have appeared in Poland relatively recently. Their exact numbers and influence on native fauna and flora are poorly understood. Therefore, monitoring of jackals should be started in order to improve understanding of this species. In the future this may allow to acquire knowledge about this species and help in managing its population. The methods presented in this article are intended to facilitate monitoring of jackals, although in the future it might require adjustments when the situation of golden jackals' population in Poland changes.

\section{ACKNOWLEDGEMENTS}

I am grateful to the professor Joanna Gruszczyńska for all the help in the preparation of this research, as well as for all the words of constructive criticism that facilitated the writing of this article.

\section{REFERENCES}

Arnold J., Humer A., Heltai M., Murariu D., Spassov N., Hackländer K. 2012. Current status and distribution of golden jackals Canis aureus in Europe. Mammal Rev. 42(1), 1-11.

Bošković I., Ozimec S., Šperanda M., Šprem N., Degmečić D., Ćurović M., Spalević V., Florijančić T. 2015. Morphometric Characteristics of the Golden Jackal Populations in Eastern Croatia and Eastern Serbia. Agriculture and Forestry 61(3), 61- 68. 
Ćirović D., Penezić A., Krofel M. 2016. Jackals as cleaners: Ecosystem services provided by a mesocarnivore in human-dominated landscapes. Biol. Conserv 199, 51-55.

Council Directive 92/43/EEC of May 21st 1992 on the conservation of natural habitats and of wild fauna and flora. OJ L 206, 22.7.1992, p. 7 - Annex V.

Gherman C.M., Mihalca A.D. 2017. A synoptic overview of golden jackal parasites reveals high diversity of species. Parasit. Vect. 10(1), 1-40.

Giannatos G. 2004. Conservation Action Plan for the golden jackal (Canis aureus L.) in Greece. WWF Greece, 47.

Golden Jackal - Canis aureus - facts, https://www.lcie.org/Large-carnivores/Golden-jackal, access: 11.07.2020.

Hoffmann M., Arnold J., Duckworth J.W., Jhala Y., Kamler J.F., Krofel M. 2018. Canis aureus. The IUCN Red List of Threatened Species 2018, https://www.iucnredlist.org/species/118264161/ 163507876, access: 11.07.2020.

Jenks K.E., Aikens E.O., Songsasen N., Calabrese J., Fleming C., Bhumpakphan N., Wanghongsa S., Kanchanasaka B., Songer M., Leimgruber P. 2015. Comparative movement analysis for a sympatric dhole and golden jackal in a human-dominated landscape. Raffles Bull. Zool. 63, 546-554.

Karolewska M. 2019. Środowiskowe i społeczne uwarunkowania rozwoju populacji szakala złocistego (Canis aureus L.) w Polsce. Praca Inżynierska. Warszawa, SGGW (niepublikowana). [in Polish]

Kowalczyk R., Kołodziej-Sobocińska M., Ruczyńska I., Wójcik J.M. 2015. Range expansion of the golden jackal (Canis aureus) into Poland: first records. Mamm. Res. 60(4), 411-414.

Lanszki J., Schally G., Heltai M., Ranc N. 2018. Golden jackal expansion in Europe: First telemetry evidence of a natal dispersal. Mamm. Biol. 88, 81-84.

Lapini L., Friulano M., Molinari P., Friulano M. 2009. Reproduction of the golden jackal (Canis aureus moreoticus I. Geoffroy Saint Hilaire 1835) in Julian Pre-Alps, with new data on its range expansion in the high-adriatic hinterland (Mammalia, Carnivora, Canidae). Boll. Mus. civ. St. nat. Venezia 60, 169-186.

Macdonald D.W. 1979. The flexible social system of the golden jackal, Canis aureus. Behav. Ecol. Sociobiol. 5(1), 17-38.

Makowska-Juchniewicz M. (ed.), 2010. Monitoring gatunków zwierząt. Przewodnik metodyczny. Część I. Warszawa, GIOŚ, 297-367. [in Polish]

Mańko O. 2020. Zmiany liczebności populacji jenota azjatyckiego (Nyctereutes procyonoides) w Polsce oraz ich wpływ na wybrane gatunki zwierząt drapieżnych. Praca Inżynierska. Warszawa, SGGW, 1-57. (niepublikowana) [in Polish]

Markov G., Lanszki J. 2012. Diet composition of the golden jackal, Canis aureus in an agricultural environment. Folia Zool. Brno 61(1), 44-48. [in Polish]

Okarma H., Tomek A. 2008. Łowiectwo, w: Łowiectwo. Kraków, Wydaw. Eduk.-Nauk. H2O Flora i Fauna. 319-321. [in Polish]

Rozporządzenie Ministra Środowiska z dnia 31 lipca 2017 r. zmieniające rozporządzenie w sprawie ustalenia listy gatunków zwierząt łownych. DzU z 2017 r., poz. 1484. [in Polish].

Rozporządzenie Ministra Środowiska z dnia 1 sierpnia 2017 r. zmieniające rozporządzenie wsprawie określenia okresów polowań na zwierzęta łowne. DzU z 2017 r., poz. 1487. [in Polish].

Šálek M., Červinka J., Banea O.C., Krofel M., Ćirović D., Selanec I., Penezić A., Grill S., Riegert J. 2014. Population densities and habitat use of the golden jackal (Canis aureus) in farmlands across the Balkan Peninsula. Eur. J. Wildl. Res., 60(2), 193-200.

Sillero-Zubiri C., Hoffmann M., Macdonald D.W. 2004. Canids: Foxes, Wolves, Jackals and Dogs. In Status Survey and Conservation Action Plan, IUCN/SSC Canid Specialist Group. 
Spassov N., Acosta-Pankov I. 2019. Dispersal history of the golden jackal (Canis aureus moreoticus Geoffroy, 1835) in Europe and possible causes of its recent population explosion. Biodivers. Data J., 7, 1-22.

Trouwborst A., Krofel M., Linnell J.D.C. 2015. Legal implications of range expansions in a terrestrial carnivore: the case of the golden jackal (Canis aureus) in Europe. Biodivers. Conserv., 24(10), 2593-2610.

Ustawa z dnia 13 października 1995r. Prawo łowieckie. DzU z 1995 r., nr 147, poz. 713. [in Polish]

\section{PROPOZYCJA MONITORINGU SZAKALA ZŁOCISTEGO (Canis aureus)}

Streszczenie. Szakal złocisty (Canis aureus) to średniej wielkości drapieżnik. Jako oportunista pokarmowy może stanowić zarówno konkurencję, jak i zagrożenie dla rodzimych gatunków. Szakal złocisty po raz pierwszy został udokumentowany na terenie Polski w 2015 roku, gdzie przybył prawdopodobnie pod wpływem naturalnej ekspansji gatunku. Obecnie na szacunkową wielkość jego populacji składają się jedynie obserwacje pojedynczych osobników, jednak w przyszłości może się to zmienić. Niedawna ekspansja szakala złocistego, jak również jego mała liczebność na terenie Polski wpływają na niski poziom wiedzy na temat gatunku oraz jego wpływu na rodzimą faunę i florę. Założeniami monitoringu jest pomoc $w$ przyszłej kontroli populacji oraz ułatwienie poznania biologii i wpływu danego gatunku na zajmowane środowisko. Monitoring szakala złocistego przedstawiony w niniejszej pracy obejmuje zarówno ocenę siedliska, w którym występuje, jak i samą populację. Ocena końcowa siedliska oraz populacji została wystawiona na podstawie ocen 7 wskaźników (są to zagęszczenie populacji, liczba miotów, wysokość nad poziomem morza, obecność wilków, dostęp do zbiorników wodnych, zarośla, dostępność bazy pokarmowej). Oceny wskaźników pozwalają określić, czy dane stanowisko sprzyja pojawieniu się i rozrostowi populacji szakala złocistego. Obserwacje prowadzone w czasie monitoringu mogą dodatkowo ułatwić poznanie gatunku na nowo zajętych przez niego terenach oraz pozwolić na określenie jego wpływu na środowisko.

Słowa kluczowe: szakal złocisty, monitoring. 
